\title{
Microbial Processing Of Spent Sorghum Grains for Possible Use as Chicken Feed
}

\author{
I. A. Onyimba ${ }^{1}$, C. I. C. Ogbonna ${ }^{1}$ C. O. Akueshi ${ }^{1}$, C. O. Chukwu ${ }^{2}$, \\ A. I. Ogbonna ${ }^{1}$ \\ ${ }^{I}$ Dept. of Plant Science and Technology, University of Jos, Nigeria \\ ${ }^{2}$ Federal College of Veterinary and Medical Laboratory Technology, National Veterinary Research Institute, \\ Vom, Nigeria
}

\begin{abstract}
The possibility of upgrading spent sorghum grains to chicken feed through microbial processing was investigated. Spent sorghum grains (SSG) were fermented for a period of 21 days at $25 \pm 2{ }^{\circ} \mathrm{C}$ using a consortium of A. niger, C. globosum and S. cerevisiae. The effects of microbial processing on the nutrient composition of the SSG were assessed and the nutrient composition of the microbe-processed product was compared with the nutrient requirements of chicken. Fermentation led to increases in the contents of crude protein (56\%), crude fat (59.65\%) and ash (38\%). Crude fibre and NFE contents were decreased by $24.84 \%$ and $35.43 \%$ respectively. Energy content increased by $7.8 \%$. The percent dry matter values of fifteen amino acids ( lysine, histidine, arginine, aspartic acid, glutamic acid, proline, glycine, alanine, cystine, valine, methionine, isoleucine, leucine tyrosine and phenylalanine) were found to increase. Elemental analysis revealed increases in the values of calcium, phosphorus, potassium and iron, and decreases in the values of magnesium, manganese, copper and zinc. Microbial processing with the test organisms generally enhanced the nutritional quality of SSG, but for it to be used as chicken feed, there is need for further fibre reduction, energy enhancement and mineral supplementation.
\end{abstract}

Keywords: chicken, feed, microbial, processing, spent sorghum grains

\section{Introduction}

Most developing nations, including Nigeria, continually generate abundant quantities of agroindustrial residues such as brewer's spent grains (BSG), which are underexploited. Brewer's grains, the main by-product of the brewing industry, representing approximately $85 \%$ of total by-products generated, is rich in cellulose and non-cellulosic polysaccharides and has a strong potential to be recycled [1]. The grains are used in Nigeria as animal feedstuff, but this use is limited, especially in the feeding of monogastric animals mostly due to high crude fibre content of the grains. A number of workers have attempted to improve the nutritive value of agro-based byproducts including BSG with different levels of success ([2], [3]). This often involves the extracellular hydrolytic enzymes activities of microorganisms. Microbial enzymes are notably produced by moulds, yeasts, bacteria and actinomycetes. These microorganisms are capable of producing diverse hydrolytic enzymes that are able to catalyze the breakdown of different organic polymers such as starch, cellulose, protein, lipids, xylan, chitin and pectin into simpler monomeric compounds such as glucose, maltose, limit-dextrin, amino acids, esters and so on for their nutrition, thus adding value to the final products. The present study was an attempt to upgrade brewery spent sorghum grains (SSG) to chicken feed using a consortium of Aspergillus niger, Chaetomium globosum and Saccharomyces cerevisiae.

\subsection{Experimental substrate and test organisms}

\section{Material and Methods}

The spent sorghum grains (SSG) used in the work were obtained from the Jos International Brewery. Two of the test organisms namely Aspergillus niger and Saccharomyces cerevisiae were isolated from naturally fermenting spent sorghum grains while the third organism, Chaetomium globosum, was isolated from naturally fermenting sweet potato leaves. The isolates were characterized and identified using identification manuals including [4], [5] and [6]. Reference was also made to existing stock cultures of some of these species of organisms in the Department of Plant Science and Technology of the University of Jos.

\subsection{Experimental procedure}

Twenty grammes each of dry spent sorghum grains (SSG) were weighed into six $250 \mathrm{ml}$ conical flasks and then moistened with $35 \mathrm{ml}$ of clean water. The content of each flask was thoroughly mixed using a spatula. An aeration apparatus consisting of a rubber cork with two glass tubes running through its middle was tightly fitted to the mouth of each of the flasks. The outer ends of the glass tubes were plugged with cotton wool and 
then covered with aluminium foil. The whole setup was sterilized by autoclaving for 15 minutes at $121^{\circ} \mathrm{C}$ and 1 $\mathrm{kg} / \mathrm{cm}^{2}$ and then allowed to cool to room temperature. The sterilized SSG in three of the flasks were, with the aid of sterile pipettes, inoculated with $3 \mathrm{ml}$ of inoculum containing $1 \mathrm{ml}$ of A. niger spores $\left(2.14 \times 10^{6}\right.$ spores $/ \mathrm{ml}), 1 \mathrm{ml}$ of C. globosum spores $\left(2.34 \times 10^{6}\right.$ spores $\left./ \mathrm{ml}\right)$ and $1 \mathrm{ml}$ of $S$. cerevisiae cells $\left(3.96 \times 10^{6}\right.$ cells $/ \mathrm{ml}$ ). The contents of the other three flasks were not inoculated and these served as controls. The inoculated samples were mixed thoroughly with the aid of surface-sterilized spatula. This helped to make sure that the fungal spores and yeast cells were evenly distributed. The pieces of aluminium foil covering the mouths of the glass tubes were removed and the inoculated substrates were allowed to undergo aerobic fermentation for a period of 21 days at $25 \pm 2^{\circ} \mathrm{C}$. After the fermentation period all the flasks, with their contents, were sterilized by tyndalization, dried at $60{ }^{\circ} \mathrm{C}$ in a hot air oven, blended with the aid of a sterile domestic dry blender and then stored in sterile air-tight bottles. Determinations of proximate compositions of the fermented and non fermented substrates were made using the method of [7]. Energy content of the substrates was assessed using recommended general conversion factors for food energy $(4,4,9 \mathrm{kcal} / \mathrm{g}$ for protein, carbohydrate and fat respectively) [8]. The amino acids profiles of the fermented and non fermented substrates were determined with the aid of a Technichon Sequential Multi-sample (TSM) amino acid analyzer using the method described by [9] while their elemental contents were assessed using the MiniPAL 4 model Energy Dispersive X-Ray Fluorescence Spectrometry (ED-XRFS). The results obtained for the fermented and non fermented materials were compared. The nutrient composition of the fermented product was further compared to the nutrient requirements of chicken. Statistical analysis of results obtained was carried out using Analysis of Variance at $5 \%$ significance level [10]. Least significant difference (LSD) was used to separate means with significant differences.

\section{Results and Discussion}

Fermentation of spent sorghum grains (SSG) with the consortium of A. niger, C. globosum and S. cerevisiae led to significant increases $(\mathrm{P}<0.05)$ in the contents of crude protein $(56 \%)$, crude fat $(59.65 \%)$ and ash $(38 \%)$. The values for crude fibre and nitrogen free extract decreased significantly $(\mathrm{P}<0.05)$ by $24.84 \%$ and $35.4 \%$ respectively. Energy content increased by $7.8 \%$ from 292.29 to $315 \mathrm{kcal} / 100 \mathrm{~g}$. Details of the effects of fermentation by the test organisms on the nutrient compositions of SSG is presented in TABLE 1.

Table 1: Effects of Fermentation with a Consortium of A. niger, C. globosum and S. cerevisiae on the nutrient composition of Spent Sorghum Grains

\begin{tabular}{llccccc}
\hline SUBSTRATE & \multicolumn{7}{c}{ NUTRIENT } \\
\cline { 2 - 7 } & DM & CP & CF & FAT & ASH & NFE \\
\hline Non Fermented & 93 & 27.85 & 24.19 & 2.85 & 6.30 & 38.81 \\
Fermented & 92 & 43.51 & 18.18 & 4.55 & 8.70 & 25.06 \\
\hline
\end{tabular}

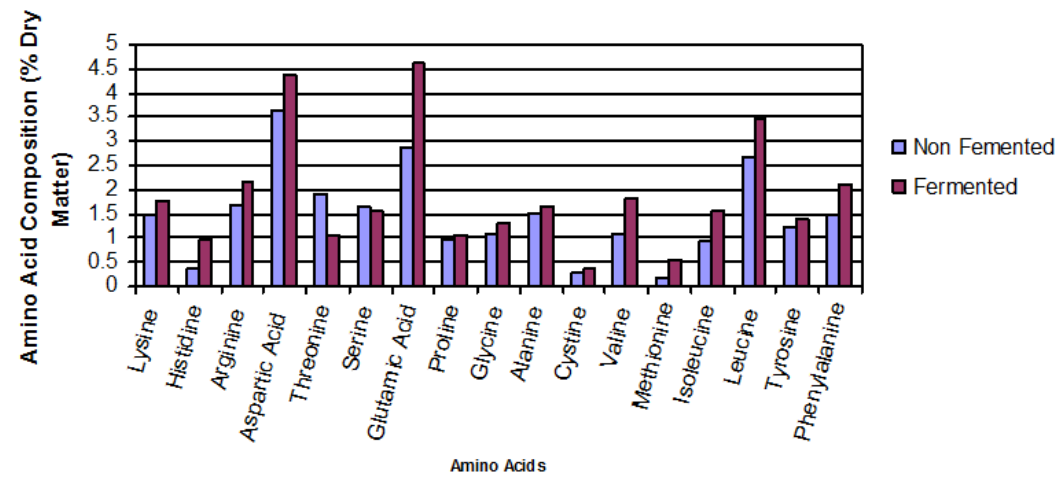

Figure 1: Amino acid profile of non fermented and fermented spent sorghum grains

The percent dry matter values of fifteen amino acids ( lysine, histidine, arginine, aspartic acid, glutamic acid, proline, glycine, alanine, cystine, valine, methionine, isoleucine, leucine tyrosine and phenylalanine) were found to increase while the values of two amino acids (threonine and serine) were found to decrease. Details are given in Fig. 1. 
Elemental analysis revealed increases in the values of calcium, phosphorus, potassium and iron, and decreases in the values of magnesium, manganese, copper and zinc. Details are presented in Fig. 2.



Figure 2: Elemental composition $(\mathrm{mg} / \mathrm{kg})$ of non fermented and fermented spent sorghum grains

The observed increase in crude protein content of the substrate (TABLE 1) resulted from protein synthesis by the microorganism using simple breakdown products from the substrate. This increase in protein content is in conformity with the findings of [11] who reported protein enrichment in sweet potato subjected to solid state fermentation. Similarly, [12] reported protein enrichment in cassava by-products through solid state fermentation by fungi. The $43.51 \%$ protein content of the fermented spent grains is comparable to the protein content (44 to $48 \%$ ) of soy meal feed, a widely used source of animal feed [13]. The Fermented SSG can therefore be rated highly as a protein source capable of meeting the $20-22 \%$ protein requirement of chickens ( [14]; [15] ).

The recorded increase in fat content could mean increase in the energy content of the fermented substrate. Fat serves as a secondary source of energy for birds. The fat content (4.55\%) of the Fermented SSG is adequate to meet the 3.5-5\% requirement for different types and ages of chicken [15].

The observed reduction in the crude fibre content of SSG was probably due to the fibre-degrading activities of the fungi, A. niger and C. globosum. Degradation of fibre by these fungi have been reported [16];[17] . High crude fibre content in diets of animals, including chickens, often pose problems of digestibility and reduced feed intake, which leads to reduced animal performance [18]. The decrease in fibre content of the fermented SSG was therefore a plus. The final crude fibre value of $18.18 \%$ was, however, still higher than the maximum 3.5 - $4 \%$ requirement for chicken [15]; [19] .

The decrease in the substrate's NFE value due to fermentation is consistent with the findings of [2] who reported that the soluble carbohydrate values of agro-industrial byproducts fermented with species of Aspergillus and Penicilium decreased after 14 days. The lower NFE value obtained was probably due to conversion of simple carbohydrates from crude fibre degradation by the fungi into other cell components. The $315 \mathrm{kcal} / 100 \mathrm{~g}$ gross energy content of the fermented SSG may be adequate to meet the $300 \mathrm{kcal} / 100 \mathrm{~g}$ metabolizable energy requirement of chickens [14] depending, however, on the digestibility of the energyproviding nutrients of the fermented material.

Microbial processing improved the amino acid profile of the SSG (Fig. 1). This finding is similar to that of [20] and [21]. The essential amino acid composition of fermented SSG meets the [22] requirements of these amino acids for chickens.

Calcium and phosphorus, based on their importance, are the two most commonly assayed mineral elements in feeds [14]. Among other uses, calcium is important for the formation of bones, cartilage and teeth in animals. Phosphorus on the other hand is a constituent of amino acids, cell membranes and energy compounds such as adenoisine triphosphate (ATP). The increases observed in the values of calcium and phosphorus (Fig. 2) are therefore noteworthy. Their final contents in the upgraded substrate, however, still fell short of the requirements for chickens. Though there was an increase in the value of potassium, its final content was lower than the recommended value. Despite the decreases in the levels of zinc, manganese, iron and copper, their final levels remained adequate for chicken diet. Calcium, phosphorus, iron, iodine, manganese, zinc and selenium represent the major minerals required by birds [3]. Fermented SSG was found to be adequate in terms of iron, zinc, manganese and copper but needs to be supplemented with some other deficient mineral elements.

\section{Conclusion}

Microbial processing of spent sorghum grains with a mixed culture of A. niger, C. globosum and S. cerevisiae generally improved the nutrient composition of spent sorghum grains. Fermented spent sorghum grains can supply a good portion of the nutritional needs of chicken. With mineral supplementation, further fibre 
reduction and probably energy enhancement, microbe-processed spent sorghum grains could serve as feed for chicken depending, of course, on the outcome of feeding trials.

\section{References}

[1] S. Aliyu, and M. Bala, Brewer's spent grain: a review of its potentials and applications, African Journal of Biotechnology, 10(3), 2011, 324-331.

[2] E. A. Iyayi and Z. A. Aderolu,. Enhancement of the feeding value of some agro-industrial by-products for laying hens after their solid state fermentation with Trichoderma viride, African Journal of Biotechnology, 3 (3), 2004, 182-185.

[3] J. P. Essien, I. R. Udotong, M. Bassey, and N. Asamudo, Bioconversion of brewers spent grains for possible use as poultry feed, World Journal of Applied Science and Technology, 2010, 2(2), 197 - 203

[4] K. H. Domsch, W. Gam, and T. Anderson, Compendium of soil fungi (London: Academic Press Limited, 1980).

[5] R. A. Samson, E. S. Hoekstra and C. A. N. Van Oorschot, Introduction to food-borne fungi (Netherlands: Institute of the Royal Netherlands Academy of Arts and Sciences, 1984).

[6] N. J. W. Kreger-van Rij, The Yeasts: a taxonomic study, (Amsterdam: .Elsevier-North, 1984).

[7] Association of Official Analytical Chemists (AOAC), Official methods of analysis (Arlington: AOAC, 1980).

[8] Food and Agricultural Organisation, Food energy - methods of analysis and conversion factors (Rome: Food and Agricultural Organisation of the United Nations, 2003)..

[9] D. H. Spackman, E. H. Stein and S. Moore, Automatic recording apparatus for use in the chromatography of amino acids, Analytical Chemistry, 1958, 30, 1190-1191.

[10] J. H. Zar,. Biostatistical analysis, (Englewood Cliffs, NJ: Prentice Hall, 1974).

[11] O. A. Abu, Biochemical characteristics and utilization of processed sweet potato - Ipomoea batatas (L.) LAM for rabbit feeding, doctoral thesis, University of Ibadan, Ibadan, Nigeria, 1997.

[12] E. A. Iyayi and D. M. Losel, Protein enrichment of cassava by-products through solid state fermentation by fungi, The Journal of Food Technology in Africa, 2001, 6(4), 116-118.

[13] G. L. Cromwell, Soybean meal - "the gold standard" ( http://www.uky. edu/Ag/AnimalSciences/pubs/soybeanmeal-thegold standard.PDF, 1999)

[14] Food and Agricultural Organisation, Poultry feeding in tropical and sub-tropical countries, (Rome: Food and Agricultural Organisation of the United Nations, 1965).

[15] L. G. G. Chinke, Some agricultural investment opportunities in Nigeria (A practical Guide), (Jos: Chinke Lenke Publishers, 2000).

[16] Y. W. Han, Microbial utilization of straw, Advances in Applied Microbiology, 1978, 25, 119-153.

[17] C. I. C. Ogbonna, The effects of Nigerian fungi on Nigerian wood, doctoral thesis, University of Technology, Aston, Birmingham, 1980 .

[18] S. Demeke, Comparative nutritive value of Atella an industrial brewers grains in chicken starter ration in Ethiopia (http://www.1n .lrrd.org/lrrd19/1/deme19008.htm, 2007).

[19] A. J. Smith, The tropical agriculturist ( London: Macmillan Publishers, 1990).

[20] M. A. Delgado, J. Guerrero and J. Conde, Genetic and biochemical study of threonine over-producing mutant of Saccharomyces cerevisiae, Journal of Molecular and Cellular Biology, 1982, 2,731-736.

[21] U. Tosaka, H. Enei and Y. Hirose, The production of lysine by fermentation, Trends in Biotechnology, $1983,1,70-74$.

[22] Food and Agricultural Organisation, Energy requirements and protein requirements (Rome: Food and Agricultural Organisation of the United Nations, 1973). 